Agnieszka Jeż

ORCID: https://orcid.org/0000-0002-1187-4200

Uniwersytet Warszawski

Wydział Nauk o Kulturze i Sztuce

Instytut Muzykologii

\title{
Pejzaż dźwiękowy sztetla we wspomnieniach dzieci i młodzieży żydowskiej w międzywojennej Polsce
}

\author{
The soundscape of the shtetl in the memories of Jewish \\ children and youth in the interwar period in Poland
}

\begin{abstract}
The article is an attempt to present the soundscape of small town in interwar Poland. The shtetl's audiosphere was built by the sounds of everyday life embedded in its topography, subject to the rhythms of human life, seasons and social events - the everyday life, a part of which was also music. The ethnic and cultural diversity represented by the local community was reflected in the sphere of its musical activity. Jewish children watched this world from a different perspective than did the adults. From an early age, the "music of the shtetl" shaped their identity, which was based on a strong identification with their own group, but also on an inseparable bond with their immediate surroundings. By participating in life, children were not only passive recipients of the audiosphere, but also contributed to its enrichment, slowly preparing the shtetl for the transformations of modern times.
\end{abstract}

Keywords: town, audiosphere, soundscape, Jewish holidays, Jews, child

Artykuł stanowi próbę przybliżenia pejzażu dźwiękowego małych miasteczek w międzywojennej Polsce. Audiosferę sztetla budowały osadzone w jego topografii dźwięki podlegające rytmom życia ludzkiego, pór roku i wydarzeń społecznych - dźwięki codzienności, której częścią była też muzyka. Różnorodność etniczna i kulturowa, jaką przedstawiała miejscowa społeczność, odzwierciedlała się w sferze jej aktywności muzycznej. Dzieci żydowskie obserwowały ten świat z innej perspektywy niż dorośli. „Muzyka miasteczka” już od najmłodszych lat kształtowała ich tożsamość, opartą na silnej identyfikacji z własną grupą, lecz także 
na nierozerwalnej więzi z najbliższym otoczeniem. Uczestnicząc w życiu, dzieci nie tylko były biernymi odbiorcami audiosfery, lecz same przyczyniały się do jej wzbogacania, przygotowując powoli sztetl do przemian czasów nowoczesności.

Słowa kluczowe: miasteczko, audiosfera, pejzaż dźwiękowy, święta ży,dowskie, Żydzi, dziecko

Odebrano / Received: 18.12.2020

Zaakceptowano / Accepted: 05.10.2020

Pejzaż dźwiękowy, zwany też audiosferą, to całokształt zjawisk akustycznych, doświadczany słuchowo przez obserwatora $\mathrm{w}$ danym miejscu i w konkretnym czasie ${ }^{1}$. Podobnie jak świat wizualny, rządzi się swoimi prawami. Składają się nań wszelkie wrażenia dźwiękowe, stanowiące rodzaj obrazu z bliższym i dalszym planem, ze zjawiskami dominującymi i takimi, które pełnią rolę kolejnych planów i tła akustycznego. Wszystko to wpływa na niepowtarzalny fenomen miejsca. Wśród elementów pejzażu dźwiękowego wyróżniamy odgłosy natury (zwane też musica naturalis) i te generowane przez człowieka w sposób przypadkowy lub celowy (musica humana). Do ostatnich należy muzyka (musica artificialis) (Muszkalska 2012: 256-257). Towarzyszyła ona małym mieszkańcom sztetla ${ }^{2}$ przez całe życie od kołyski, milkła dopiero po ich śmierci w towarzyszącej żałobie ciszy.

Zazwyczaj przywiązuje się znacznie mniejszą wagę do świata otaczających nas dźwięków niż do przestrzeni percypowanej za pomocą wzroku. A jednak mają one wpływ na świadomość człowieka i kształtowanie się osobowości w młodym wieku. Zapisują się w pamięci małych dzieci zanim jeszcze są one w stanie nazwać i zrozumieć otaczająca je rzeczywistość. Pozostają tam związane z przeżytymi emocjami, gotowymi ujawnić się nawet po wielu latach, w zupełnie innych okolicznościach. Towarzyszą wzrastaniu, współtworząc unikalną, lokalną tożsamość i więzy z miejscem zamieszkania, które sprawiają, że dźwięki z otoczenia określane są jako „swojskie”. Każda większa zmiana życiowa daje się od razu „usłyszeć”. Zmysł słuchu u człowieka, w przeciwieństwie do wzroku, podlega zjawisku akomodacji, które sprawia, że różnica w percepcji jest odczuwalna dopiero przy zmianie siły bodźców słuchowych. Zjawiska o stałym natężeniu, tworzące dźwiękowe tło, przestają być świadomie rejestrowane. Nie tak łatwo zatem jest znaleźć opisy dźwiękowych światów w źródłach z przeszłości, gdyż wymaga to

1 Pierwszy raz terminu tego użył Alvin Lucier w 1965 r. Badania nad pejzażem dźwiękowym zainicjował Raymond Murray Schaffer, założyciel World Soundscape Project.

2 Sztetl (jid. miasteczko) - małe miasto z rynkiem w Europie Środkowo-Wschodniej przed II wojną światową, z przynajmniej 40-procentową populacją żydowską, w którym znajdowały się budynki synagogi, mykwy, chederu oraz cmentarz żydowski (Teller 2004: 25-40; Kassow 2008; Petrovsky-Shtern 2014: 18). 
spojrzenia $z$ dystansu, z innego już miejsca i czasu, swego rodzaju wspomnień z podróży sentymentalnej. W przypadku dzieci żydowskich, mieszkańców przedwojennych sztetli w Polsce, takich świadectw pozostało niewiele. Niektórym z tych, którzy przeżyli, udało się spisać swoje wspomnienia, w których powracali do miejsc dzieciństwa, nieraz szczegółowo wspominając detale, tak ważne dla nich wówczas, gdy byli małymi dziećmi. Po innych zostały materiały pisane w czasie przedwojennym, przechowane w dokumentach i prasie. Wśród tytułów, które zachowały takie świadectwa, nieocenionym źródłem jest „Mały Przegląd”3. Najwięcej aktywnych czytelników pochodziło z Warszawy, pismo docierało jednak też na prowincję, co redaktorzy starali się docenić, publikując relacje dzieci w specjalnych cyklicznych rubrykach. Ich teksty zawierają bezcenne wspomnienia, fragmenty „małej historii” codzienności, dostrzeżone i zanotowane ze świeżością obserwacji właściwą okresowi dzieciństwa, gdy niemal wszystko wydaje się ciekawe i godne uwagi. Dzieci obserwowały swoje otoczenie, którym był dom, szkoła, synagoga, najbliższe ulice czy rynek w miasteczku. Nie tylko widziały je, ale i słyszały, rejestrując mniej lub bardziej świadomie pulsowanie dźwiękowego pejzażu w rytmie godzin, dni, tygodni, miesięcy. Każda pora dnia, tygodnia, czy roku mogła mieć swoją barwę, charakterystyczną na tyle, by z zamkniętymi oczami móc zgadnąć, jaki to dzień, czy nawet która godzina. Niektóre z dzieci, bardziej zapewne wrażliwe na ten rodzaj percepcji, wychwytywały to pulsowanie, opisując zmienność scenerii i przestrzeni dźwiękowej w jednym miejscu podczas upływu dnia. Miejscem tym mogło być podwórko czy najbliższa ulica, a punktem obserwacji chociażby okno w rodzinnym domu. Takie opisy są zazwyczaj dokładne i wierne, gdyż ich autorzy skupili się właśnie na rejestrowaniu interesującej ich codzienności, sami pozostając w bezruchu, dzięki temu bardziej wrażliwi na zachodzące w otoczeniu zmiany.

Pisząc o najmłodszych członkach społeczności żydowskiej w małym miasteczku w międzywojennej Polsce, wkraczamy w świat niejednorodny. Mimo dużo większej homogeniczności politycznej, ekonomicznej czy kulturowej Żydów w sztetlu, niż to można było spotkać w większym mieście, mamy do czynienia ze stratyfikacją społeczną. Wynikające z niej różnice przekładały się w sposób oczywisty na warunki, w jakich wychowywały się dzieci, a więc i na ich najbliższe otoczenie i jego dźwiękowe upostaciowanie. Inaczej „słyszały świat” dzieci z tradycyjnych rodzin przestrzegających zasad judaizmu i utrzymujących dystans do nieżydowskiego otoczenia, inaczej zaś te, które żyły w rodzinach o większym stopniu asymilacji, czy wychowujące się $\mathrm{w}$ środowisku świeckich syjonistów. Różnice te dotyczyły głównie takich miejsc, jak szkoła, dom, czy bóżnica. Muzyka towarzysząca dzieciom podczas wizyt w synagodze, domowej celebracji świąt, na lekcjach śpiewu w szkole czy na pogadankach podczas spotkań rozmaitych

\footnotetext{
3 „Mały Przegląd” - dodatek cotygodniowy do żydowskiego dziennika w języku polskim „Nasz Przegląd”. Ukazywał się w latach 1926-1939, pomysłodawcą i redaktorem był Janusz Korczak, zastąpiony w 1932 roku przez Jerzego Abramowa.
} 
ruchów młodzieżowych mogła pełnić różne funkcje, nieraz zresztą więcej, niż jedną na raz. W zamieszkiwanym przez Żydów sztetlu ważna była funkcja religijna, zogniskowana na przekazie tradycji judaizmu, towarzysząca ceremoniom w synagodze i celebracji świąt $\mathrm{w}$ domu. $\mathrm{W}$ wielu przypadkach rozbrzmiewająca $\mathrm{w}$ przestrzeni miasteczka muzyka miała charakter czysto ludyczny i służyła rozrywce. Waluacja estetyczna muzyki była $z$ kolei sprawą indywidualnych preferencji i wydaje się, że dostarczanie przeżyć o charakterze estetycznym nie było w miasteczku funkcją prymarną muzyki, lecz raczej pochodną jej pozostałych ról. Zjawisko to ulegało jednak powoli zmianie wraz z implantowaniem elementów kultury miejskiej i najnowszych zdobyczy techniki.

Nie sposób nie docenić też funkcji integracyjnej muzyki. Jej działanie przebiegało na różnych poziomach i dotyczyło zarówno małych grup, jak i większej liczby mieszkańców, a sama integracja mogła być chwilowa i przypadkowa bądź też być częścią długotrwałego procesu. Bardzo istotna była również funkcja ideologiczna muzyki i jej rola w edukacji młodego pokolenia. Dobór repertuaru i jego komunikacyjny aspekt był przedmiotem świadomej refleksji i wyboru. Muzyka, a w szczególności tekst, który jej towarzyszył, przekazywały określone treści ideowe. Doniosłości i skuteczności tego przekazu były świadome zarówno religijne, jak i pedagogiczne autorytety w tym czasie, prowadząc nieustanną „walkę o dusze” młodych. Ulica zaś dla wszystkich brzmiała dosyć podobnie, w małym mieście niewielka odległość dzieliła poszczególne kwartały, zamieszkiwane przez zróżnicowane grupy ludności. Naturalna ciekawość dzieci przełamywała nieraz ograniczenia w przestrzeni, a bliskie sąsiedztwo „innych” - gojów, ale także i Żydów należących do różnych opcji kulturowych - poszerzało pole doświadczeń, będąc okazją do konfrontacji własnych postaw z odmiennymi wzorcami. W wielu przypadkach ułatwiało to, przynajmniej na początkowym etapie, samookreślenie jednostki i kształtowanie jej kulturowej tożsamości wewnątrz rodzimej grupy. Nieraz jednak dochodziło do zmian statusu jednostek we własnej grupie poprzez częściową akulturację z „innymi”, a nawet do całkowitego porzucenia własnego środowiska. Zjawisko to, przedtem marginalne, zaczęło być szczególnie zauważalne właśnie w dwudziestoleciu międzywojennym, dobie wielkich zmian społecznych w środowisku żydowskim (Kijek 2017: 88). Zawsze jednak taki kontakt pozostawiał ślad, nawet, gdy jednostka nie decydowała się na radykalną zmianę w swoim życiu. Kształtowała się niepowtarzalna lokalna tożsamość, której ważnym elementem była zarówno własna grupa religijna, narodowa i społeczna, lecz także poczucie przynależności do miejsca, przywiązania do elementów odbieranych jako obce, a jednak niezbędne w lokalnym krajobrazie, zarówno wizualnym, jak i dźwiękowym. Ta rysa czy wręcz rozdarcie, będąca nieodłącznym elementem „tożsamości diaspory”, widoczna jest czasem w autobiograficznych wspomnieniach, gdzie nieraz w retrospekcji poczucie wyobcowania miesza się z ogromną czułością i przywiązaniem, kierowanym nie tylko do bliskich osób, ale także do zapamiętanej w dzieciństwie przestrzeni miasteczka czy natury. 
Każdy sztetl miał swój własny pejzaż dźwiękowy. Wiązało się to z wielkością miasteczka, jego uprzemysłowieniem, dostępnymi środkami transportu, położeniem geograficznym, strukturą zawodową i etniczną mieszkańców. Były jednak do siebie na swój sposób podobne, podlegając tym samym rytmom, związanym $z$ religią, pracą i odpoczynkiem w cyklach dziennych, tygodniowych i rocznych. Obchodzenie świąt przez żydowskich mieszkańców, aczkolwiek odbywające się zazwyczaj w synagodze lub zaciszu domowym, przynajmniej częściowo dawało się usłyszeć na ulicach miasteczek, choć tylko nieliczne wydarzenia miały miejsce na zewnątrz. Charakter zabudowy przedwojennego sztetla, najczęściej parterowej i drewnianej, nie był szczelną barierą dla dźwięków; bliskie zazwyczaj sąsiedztwo współwyznawców czy wręcz ciasnota sprawiały, że uroczyste śpiewy słyszane były przez sąsiadów i przechodniów.

Najważniejszym świętem żydowskim, regulującym cotygodniowy rytm pracy i odpoczynku jest dzień szabatu. Świętość tego czasu obwarowana jest wieloma regułami, których przestrzeganie jest obowiązkiem każdego religijnego Żyda. Przejście od tygodniowego zabiegania w rytmie chronosu, trosk i ciężkiej pracy do bycia w rzeczywistości niejako poza czasem, uroczystego świętowania i radości, było przywilejem i obowiązkiem nawet najbiedniejszych członków społeczności. Przygotowania rozpoczynano nieraz kilka dni wcześniej. Największy ruch i gwar miał miejsce w piątki. Trwał do chwili rozpoczęcia szabatu, kiedy robiło się cicho, aż do początku wieczornego nabożeństwa $\mathrm{w}$ synagodze, a potem śpiewania zmirot (hebr.) przed uroczystą kolacją w domu. W tym przypadku religijna funkcja muzyki zyskiwała dodatkowy wyróżniający aspekt, pozwalający podkreślić sakralny charakter czasu. Jedna z czytelniczek „Małego Przeglądu” zamieściła następujący opis, w którym po równo mieszają się wrażenia wzrokowe, słuchowe i węchowe, oddające intensywność przeżywanej chwili:

Lipiec spędziłam w małym żydowskim miasteczku pod Lublinem. Wieczorami siedziałam przy otwartym oknie i wyglądałam na wąską uliczkę. W piątek wieczorem panował wielki ruch. Małe dziewczynki niosły garnki ciulentu [sic!] do piekarza. Słychać było głosy matek, które wołały do dzieci, aby szły się umyć. Żydzi spieszyli do domów. Dolatywał zapach gotowanej ryby. Powoli zrobiło się coraz ciszej. Zapadał zmierzch. W niektórych oknach widziałam już zapalone pierwsze świeczki sobotnie. Na ulicy zaczęli się zjawiać Żydzi w świątecznych kapotach, $\mathrm{z}$ modlitewnikami, w drodze do pobliskiej bóżnicy. $Z$ bóżnicy ludzie wychodzili grupami i zamieniwszy ze sobą parę słów, w milczeniu udawali się do domu. Po chwili słychać było śpiew przed sobotnią kolacją (Hanka ze Złotej 1931:3).

W miasteczku, gdzie niewiele osób miało zegar, potrzebne było przypomnienie o nadchodzącym szabacie. Rolę taką mógł pełnić szames (jid.; sługa bóżniczy). Zazwyczaj obchodził on żydowską część sztetla, nawołując do zamykania sklepów. Niekiedy posługa ta mogła przybrać bardziej artystyczną formę, jak w poniższym wspomnieniu: 
Po tygodniu pracy nadchodził odpoczynek w miasteczku. Piątek wieczorem wszystko zwykło się uspokajać, ulica przygotowywała się do szabatu. W dzielnicy pojawiał się reb Lejzer szamesz ze swoimi ładnymi melodiami, które nadal dźwięczą w moich uszach: „Jidn licht cinden"(jid. Żydzi zapalcie świece) - przypominał przechodniom (Kanarek 2016: 65).

Soboty w sztetlu były dużo cichsze niż pozostałe dni. Ustawała praca, a więc i wszystkie odgłosy generowane przez aktywności zawodowe społeczności żydowskiej: handel uliczny, dźwięki dochodzące z warsztatów szewskich i krawieckich, rzeźni, sklepów. Modlitwom w bóżnicy i w domu nie towarzyszyły dzwony ani instrumenty muzyczne, jak to miało miejsce $\mathrm{w}$ kościołach. W szabat obowiązywał zakaz gry4 W modernizującym się z wolna społeczeństwie międzywojnia zdarzało się coraz częściej łamanie tego i innych zakazów religijnych, wciąż jednak wywoływało to reakcję bardziej zachowawczej grupy. Jeden z czytelników „Małego Przeglądu”, autor drukowanego w odcinkach pamiętnika-reportażu z mazowieckiego miasteczka Zaręby Kościelne, wspominał: „Pamiętam, kiedy Szyje stał na progu domu i grał na organkach, a wujek krzyczał, dlaczego w sobotę grzeszy" (Pamiętnik Mendla 1928 B: 2).

O ile szabat był obchodzony w bóżnicy i zaciszu domu, obecność niektórych świąt zaznaczała się wyraźniej w dźwiękowej scenerii miasta. Tu muzyka integrowała już nie tylko celebrującą uroczystość rodzinę, lecz także większą społeczność miasteczka. Żydowski Nowy Rok (Rosz ha-Szana) zwany był przez chrześcijańskich sąsiadów świętem trąbek ze względu na obecność w liturgii tego dnia baraniego rogu (hebr. szofar). Dla dzieci było to ważne wydarzenie, któremu poświęcały uwagę. Już kilka dni przed świętem ćwiczono grę na rogu, co ze względu na właściwości instrumentu nie było łatwym zadaniem:

Nazajutrz chłopcy znów się spotkali w bóżnicy. Dorośli modlili się gorliwie. Potem nastąpiły ćwiczenia na trąbce z baraniego rogu. Chodziło o to, by opanować instrument. Wszyscy przysłuchiwali się, śledzili każdy ruch trębacza. Dobrze wytrąbione trele i tony - mówili chłopcy - wróżą niepowodzenie anioła - prokuratora, który oskarża. Udane dźwięki trąbki - to dobry znak. [...] Trąbkom przysłuchiwano się z zapartym tchem. Nieudany ton lub

4 Zakaz ten pochodzi z czasów rabinicznych i został zapisany w Talmudzie jako zakaz klaskania, tańca i naprawy instrumentów muzycznych podczas szabatu i wielkich świąt, jak Rosz ha-Szana czy Pesach (Talmud Babiloński, traktat Bejca, 36b). Komentowany i podtrzymany przez uczonego i talmudystę rabbiego Chananela ben Chusziela (990-1053) jako zakaz czynienia hałasu w szabat, co nie jest jedną z czynności zabronionych w ten dzień, lecz sprzeciwia się duchowi świętego odpoczynku (Talmud Babiloński, traktat Szabat, 18a-b). Podobne stanowisko zają Józef ben Efraim Karo (1488-1575), autor podstawowego wykładu prawa żydowskiego, w wydanym w Wenecji w 1565 roku dziele Szulchan aruch (Orach chaim, 338-339). I chociaż niektóre autorytety wypowiadały się na korzyść używania instrumentów podczas szabatu i świąt, zakaz ten obowiązuje w większości ortodoksyjnych gmin aż do dzisiejszego dnia. 
powtórzenie wywoływały grymasy i odruch niezadowolenia na twarzach słuchających (Jankiel 1932: 1).

Święto Rosz ha-Szana łączyło się również z obrzędem zwanym taszlich5 ${ }^{5}$. Jedno z dzieci zachowało nostalgiczne wspomnienie tego dnia:

Nigdy nie zapomnę, jak z ojcem i kilku pobożnymi Żydami chodziłem do rzeki Narew na Taszlich. [...] Kroczyliśmy $\mathrm{z}$ wolna $\mathrm{w}$ cichym zadowoleniu i pobożnej zadumie najpierw bocznymi uliczkami, potem smutnymi, pustymi polami. Ojciec mój z siwą brodą, o smutnych oczach i pogodnym wyrazie twarzy szedł w środku, jako starszy, i cichym uczuciowym głosem nucił melodię naszego ulubionego chazena Chaima Berela z modlitw Rosz Haszana. Tak szliśmy do rzeki. Nad rzeką pełno było ludzi. Na jednym brzegi stali mężczyźni z małymi chłopcami z „machzojrym” [hebr. machzor, modlitewnik świąteczny] w ręku i cicho się modlili. Naprzeciwko, na drugim brzegu, stały kobiety w jaskrawych sukniach i fartuchach i białych szalach na głowach. Głośno i gorąco się modliły. [...] Czułem, że przechodnie chrześcijanie zazdroszczą nam starych pięknych obyczajów i byłem z tego dumny (Jakób z Ostrołęki 1930: 1).

Kolejnym świętem, które zaznaczało się w przestrzeni dźwiękowej miasta, było Sukot, czyli Święto Namiotów, zwane Kuczki. Obowiązek mieszkania w wybudowanych przy domach szałasach łączył się z odprawianiem w nich modlitw i śpiewaniem pieśni. Dla dzieci ogromną atrakcją była nie tylko pomoc w budowie kuczki i spędzanie w niej czasu, lecz także odwiedzanie innych namiotów lub nawet ich podglądanie z ukrycia, co opisało jedno z nich:

Budowali kuczkę cały dzień i - zbudowali. Na podwórku stała tylko ona jedna. [...] Nazajutrz wieczorem zapalono w kuczce świece, zaczęli się schodzić chasydzi z naszego domu i sąsiednich. Wkrótce kuczka była przepełniona. Kobiety przynosiły jedzenie. Chasyd, siedzący przy drzwiach, przyjmował potrawy i podawał je gościom. Zaczęły się śpiewy. [...] Widzieliśmy starców z długimi siwymi brodami. Wszyscy śpiewali, najstarszy modlił się. Potem przyniesiono wino (Kuczki. Przez szparkę 1930: 2).

Radosne święto Sukot kończyło się ceremonią Simchat Tora (hebr. Radość Tory). Główny moment celebracji odbywał się podczas siedmiu uroczystych procesji (zwanych $h a k(k) a f o t$, hebr.) wokół synagogi (lub wewnątrz niej), czemu towarzyszyły tańce i śpiewy. Udział dzieci w tej ceremonii też był ważny. Jeden z korespondentów „Małego

5 Taszlich (hebr. „wyrzucisz”) - symboliczny obrzęd wyrzucania grzechów do płynącej wody, któremu towarzyszy odmawianie modlitw, psalmów i czytanie fragmentów Biblii, odprawiany w dniu Rosz ha-Szana. 
Przeglądu" zauważył nawet, że samo święto niesie w sobie dziecięcą radość, pozwalającą dorosłym oderwać się od trosk i cieszyć jak dziecko:

Żydzi obciążeni troskami, zmęczeni walką o byt, wyzwalają sie czasem z pęt twardej rzeczywistości, zapominają o wszystkim i stają się dziećmi. Gdzie i kiedy? - w dniu Symchat Tory - w małym miasteczku. Tam, gdzie od wieków przekazywana tradycja nie poddaje się jeszcze nowemu życiu. Minęły święta Nowego Roku i Sądnego Dnia. Bilans grzechów i dobrych uczynków został zamknięty. Głosy trąbek rogowych nie napędzają więcej strachu. Wyrok już zapadł. I serca uspokajają się powoli. (Jankiel 1931: 2).

Późnym wieczorem w wigilię święta ulice wypełniał malowniczy tłum zmierzający do synagogi:

Godzina dziewiąta wieczór. Noc ciemna. W powietrzu unoszą się dalekie i bliskie tony różnych melodii. Powietrze drga. Czujesz, że miasteczko coś przeżywa. Na ulicach, które prowadzą do bóżnicy chasydów widać dygocące światełka i tłumy ludzi. $Z$ zaułków i uliczek przybywają coraz nowe grupy. Ilość świateł się powiększa. Śpiew rośnie i wraz z nim gwar dzieci. Towarzyszyliśmy starszym w drodze z kiduszu. Starsi tańczyli w koło i śpiewali, a my chłopcy nieśliśmy latarnie. [...] Dzieci mają w rękach różnokolorowe chorągiewki z odpowiednimi napisami. Na pałeczkach chorągiewek nasadzone są czerwone jabłka lub marchewki z palącymi się świecami (Jankiel 1931: 2).

Świętem lubianym przez dzieci, niezwykle hucznie obchodzonym i wybrzmiewającym w przestrzeni miasteczek, był Purim. Grupy dzieci chodziły od domu do domu, śpiewając piosenki, za co nagradzano je słodyczami. Funkcja ludyczna muzyki w tym najbardziej chyba radosnym i widowiskowym święcie była bardzo istotna i nieraz zyskiwała większe znaczenie, niż jej ściśle religijny aspekt. Karnawałowy i transgresywny charakter święta, zakładający zawieszenie czy nawet całkowite odwrócenie dotychczasowego porządku społecznego, pozwalał im na dużo większą swobodę zachowań, manifestującą się także w możliwości ekspresji. Podległość, posłuszeństwo, milczenie zastąpione zostały głośnym wyrażaniem radości lub nawet celowo czynionym hałasem, wpisanym w obrzędowość święta. Miało to miejsce zarówno na poziomie symbolicznym, jak i rzeczywistym, słyszalnym w przestrzeni sztetla. Autor artykułu w „Małym Przeglądzie” wspomniał o tym:

Bardzo ważnego prawa były pozbawione dzieci żydowskie: prawa do krzyku i głośnego śmiechu, do wyrażania głośnej wesołości. [...] Dorośli uciszają, a dzieci swoje. Rwetes, huk grzechotek, uderzenie w pulpity i tupanie nóg. [...] W Purym mogły znów stać się ruchliwymi, hałaśliwymi i wesołymi (Walka dzieci o swoje prawa 1928: 6). 
Dzieci wykazywały się wielką inicjatywą w organizacji purimowych imprez. Wiele z nich, zwłaszcza tych uboższych, samodzielnie przygotowywało tradycyjne grzechotki zwane gregerami, używane podczas czytania Zwoju Estery:

Podczas czytania Mgyłe ${ }^{6}$, gdy się wspomina imię Hamana, powstaje straszny hałas. Tupią nogami, biją w stoły i terkoczą w gregers. Te grzechotki są różne: $\mathrm{z}$ drzewa i blaszane. Grzechotki drewniane robią chłopcy sami. Dwie deseczki wystrugują, jeden koniec w kształcie trójkąta, a drugi okrągły; trzecią deszczułkę kładą do środka. To się nazywa język. Wszystko razem spaja się pręcikami, potem robi się wałek z karbami i cienką rączką. Przy poruszeniu rączki język ociera się o wałek karbowany i robi się hałas. Zrobić dobrze greger jest bardzo trudno i wymaga dużo czasu. Czasem robota trwa parę tygodni (Nasze gospodarstwo. Purym 1929:1).

Przygotowania do wieczoru purimowego rozpoczynały się już na długo przedtem.

Rok rocznie przed świętami Purym na podwórkach odbywają się zebrania. Purym-szpiler naradzają się, co i jak będą śpiewać lub recytować. I na naszym podwórku były takie zebrania, w których nie tak dawno jeszcze żywy brałem udział, chodziłem razem z dziećmi od domu do domu śpiewając: „Hajnt yz $\operatorname{Purym}^{7}$ [...]. Każdy z nas marzył o najładniejszej masce. $\mathrm{Na}$ tekturkach malowało się najdziwaczniejszych diabłów, ludzi i głowy zwierząt. Oczywiście, wolelibyśmy maskę kupioną w sklepie, ale rzadko który z nas mógł sobie na tak cudną rzecz pozwolić. Co rok uskładaliśmy nowy repertuar, niekiedy przerabiając częściowo zeszłoroczne piosenki i inscenizacje. [...] W Otwocku Purym jest obchodzony nie tak, jak w Warszawie - hucznie i uroczyście. Dzieci nie tylko występują jako aktorzy, ale [...] rokrocznie z orkiestrą, poprzebierane i zamaskowane, długim pochodem przeciągają ulicami miasta (Szlamek z Otwocka 1931: 9).

Świętem, które miało szczególne znaczenie dla wielu dzieci, w tym także tych z mniej ortodoksyjnych środowisk, był Lag ba-Omer. Wypadał późną wiosną, gdy pogoda zazwyczaj była ładna i dlatego często urządzano tego dnia wycieczki. Dla młodych żydowskich mieszkańców sztetla był to moment, w którym i oni mogli się pokazać na ulicy w radosnym pochodzie, podobnie jak ich chrześcijańscy koledzy. Napięcia dotyczące publicznego obchodzenia świąt chrześcijańskich i narodowych polskich towarzyszyły żydowskim dzieciom w szkołach publicznych, do których uczęszczała spora ich część, a czasem nawet i w prywatnym szkolnictwie żydowskim ${ }^{8}$ Lag ba-Omer zwany także

${ }^{6}$ Hebr. Megil(1)at Ester, zwoju Księgi Estery, przyp. aut.

7 Hajnt iz Purim, popularna pieśń świąteczna.

8 „Zbliża się święto narodowe, Lag Baomer, uroczysty dzień młodzieży szkolnej. Jednakże często spotykamy się z faktem, zwłaszcza na prowincji, że gimnazja żydowskie, chcąc zaskarbić sobie zaufanie władz 
nieraz po prostu świętem młodzieży, stanowił okazję do radosnej manifestacji własnej tożsamości, pokazania się w przestrzeni sztetla i wypełnieniu jej muzyką, śpiewem i grą. Szczególnie angażowała się młodzież należąca do ruchów syjonistycznych, która z tym świętem związała wiele elementów własnej obrzędowości, ale nieraz świętowano ponad podziałami politycznymi, pokoleniowymi, a nawet religijnymi, jak to miało miejsce w Bielsku:

W Lag Baomer członkowie wszystkich ruchów wyjeżdżali razem z rodzicami na wozach do lasu. [...] Robiliśmy paradę i przechodziliśmy przez miasto z trąbkami. To był jeden dzień w roku. [...] Dyrektor szkoły, który był jednocześnie chazanem w synagodze, był liberalny i organizował wspólne wyjścia uczniów do miasta w Lag Baomer, by manifestować jedność ludu Izraela (Chrabotowski 2017: 259).

Działalność w rozmaitych ruchach młodzieżowych, z których większość zrzeszała młodych entuzjastów syjonizmu, była manifestacją ich siły i ideałów. Muzyka spełniała tu niezwykle ważną funkcję ideologiczną. Pieśni palestyńskie z tekstem w języku hebrajskim zawierały najważniejsze elementy syjonistycznego credo: miłość do kraju przodków, podziw dla jego piękna, deklarację poświęcenia i pracy dla ojczyzny, braterstwo i miłość do natury. Drugą niezmiernie istotną funkcją pieśni była ich integrująca rola: wspólne śpiewanie dawało poczucie jedności, która wykraczała poza lokalną wspólnotę i obejmowała całą syjonistyczną społeczność w diasporze i w Palestynie. W tym wypadku możemy mówić o pogłębieniu funkcji ideologicznej i o jej aspekcie kształtującym tożsamość narodową. Nie bez znaczenia był także walor edukacyjny pieśni napisanych w języku hebrajskim, którego nauka była jednym z wyzwań dla wychowanych w Polsce młodych Żydów.

Członkowie organizacji brali zazwyczaj niezwykle aktywny udział w życiu grupy, co przekładało się także na ich zaistnienie w przestrzeni miasteczka. Była to sytuacja, gdy dzieci i młodzież samodzielnie współtworzyły krajobraz dźwiękowy miasta, wnosząc do niego elementy swojej własnej obrzędowości, zabawy czy, po prostu, obecności. Choć większość spotkań odbywała się w pomieszczeniach, miały miejsce również uroczyste przemarsze przez ulice, czemu towarzyszył śpiew, a nieraz i gra orkiestry, dźwięki bębna czy trąbki, jak to miało miejsce w Mławie:

Z czasem ze skautów wyłonił się Ha-szomer ha-Cair. [...] W każdy szabat maszerują do synagogi, wierni skautowskiemu przykazaniu „Bogu i ojczyźnie”. Ten marsz, to trąbienie, walenie w bęben - to była dziwaczna nowość. Jak długo były to zwyczajne parady, rodzice

szkolnych, przesadnie nawet urządzają obchody 3-go maja, a święto Lag Baomer mija bez echa” (Lag Baomer 1929: 1). 
przyglądali się i milczeli, nawet się cieszyli. Pierwsze zderzenie z rodzicami miało miejsce, gdy zaczęto chodzić do lasów, do nieżydowskich wsi. Rodzice bali się, żeby się broń Boże nic nie stało. Gdy się nie zgadzali, trzeba było uciekać z domów (Junis 2016: 82).

Gwarancją legalności pochodów młodzieżowych dla władz były święta żydowskie, podczas których mogły się one odbywać. Zazwyczaj był to właśnie Lag ba-Omer, choć młodzi ludzie wykorzystywali także inne okazje, by uroczyście wyjść na ulice, jak to robił syjonistyczny ruch Betar w podkarpackim Bolechowie:

Gdy „Betaryści” maszerowali ulicami miasteczka w czasie święta Purim, sprawiali bardzo dobre wrażenie. Ich marsz miał na celu rekrutowanie młodzieży. Tylko przez jeden dzień w roku wolno było maszerować przez miasteczko, bo władze kwalifikowały to jako purimowe przedstawienie (Adler 2020:17).

O ile święta religijne wyraźnie dzieliły grupy etniczne zamieszkujące przedwojenny sztetl i decydowały o ich odmienności, pewne wydarzenia w miasteczku miały charakter integrujący. Wśród nich można wymienić święta narodowe polskie, którym również towarzyszyła muzyka dobierana najczęściej z repertuaru polskich pieśni patriotycznych i religijnych, pełniąca funkcję integracyjną oraz ideologiczną. Była to jednak integracja chwilowa, niepełna, bazująca raczej na narzuconej konwencji, z którą żydowscy mieszkańcy miasteczka identyfikowali się tylko częściowo i raczej powierzchownie. Zależało to oczywiście od ich poglądów politycznych, stopnia religijności i statusu społecznego. Wielu mieszkańców, szczególnie bardziej ortodoksyjnych, przywiązywało niewielką wagę do tych wydarzeń, chociaż życie miasteczka zmieniało się w taki dzień diametralnie i przechodziło na tryb świąteczny, wolny od pracy i handlu. Tymczasem grupą, która miała większą styczność $\mathrm{z}$ kulturą polską i często musiała uczestniczyć w obchodzeniu polskich świąt, były dzieci, szczególnie zaś te, które chodziły do państwowych szkół. Co ciekawe, w wielu relacjach wysyłanych do „Małego Przeglądu” znajdujemy dowody prawdziwego zaangażowania w świętowanie. Sceną uroczystości stawały się kolejno szkoła, ulice miasteczka i synagoga, czasem do tego dochodziło jeszcze świętowanie na głównym rynku, koło ratusza, czy w innym, ważnym dla miasteczka miejscu. Obowiązującym repertuarem były polskie pieśni patriotyczne, w tym hymn narodowy. Pochodom ulicznym towarzyszyła często orkiestra lub miejscowy chór. Dzieci w miasteczku, niezależnie od wyznania czy szkoły, do której uczęszczały, brały udział w wydarzeniach. Śpiewały na uroczystościach szkolnych pieśni ludowe i patriotyczne, uczestniczyły w okolicznościowym nabożeństwie w synagodze, zazwyczaj połączonym ze śpiewaniem polskiego hymnu, podążały w pochodzie ulicami miasteczka przy dźwiękach granych przez orkiestrę marszów, korzystały z organizowanych przy tej okazji imprez kulturalnych. Oto wspomnienie z obchodów dziesięciolecia niepodległości kraju: 
Od wczesnego ranka na rynku gromadzą się wieśniacy, przybyli z najbliższych wiosek. O godz. 7-ej z wieży ratuszowej rozlega się hejnał. Widać na ulicy dziatwę szkolną, idącą na miejsce zbiórek. O godz. 8-ej od strony zachodniej nadjeżdża wojsko z orkiestrą, przyłączają się strażacy, za nimi szkoły i związki. Wszyscy dążą do starostwa, gdzie z estrady przemawiał ksiądz. Po odegraniu „Jeszcze Polska nie zginęła” ruszamy na rynek. Gimnazjum męskie ma pięknie obramowany złotem sztandar. [...] Na rynku orszak rozwiązał się (Lutek 1929: 4).

Oprócz świąt narodowych żydowskie dzieci i młodzież brały udział również w innych oficjalnych wydarzeniach w miasteczku. Często pisały o odwiedzinach ważnych osobistości, które wnosiły zapewne wiele kolorytu w monotonne życie sztetla. Miasteczko witało swoich gości z muzyką, budując powitalne bramy i gromadząc się tlumnie na ulicach. Uczniowie szkół przychodzili w odświętnych strojach, ze sztandarami. Zazwyczaj w takich uroczystościach brali udział wszyscy oficjalni przedstawiciele władzy, niezależnie od narodowości:

Kiedy rozeszła się wieść, że Pan Prezydent ma zawitać do Sierpca, całe miasto przybrało świąteczny wygląd. Balkony udekorowane, domy przybrane, a okna domów zasłane dywanami. Przyjęcie odbyło się w specjalnej bramie powitania. [...] Gdy stanął samochód Pana Prezydenta, muzyka ucichła. Delegacje: polska, niemiecka i żydowska przywitały Gościa. Bardzo ładną mowę miał rabin. Potem orkiestra odprowadziła Pana Prezydenta do Rypina (Hinda 1928: 3).

Nie mniej uroczyście przeżywały miasteczka przybycie biskupa lub rabina. Takie momenty bywały rzadką okazją zetknięcia się dwóch religijnych światów, choć nie należy dopatrywać się w tych relacjach konsekwentnej symetrii.

Wkrótce ma przyjechać biskup. Chrześcijanie urządzili bramę, okryli ją dachem słomianym. Całe miasto stało dziś przy bramie [...] Żydzi też wysłali delegację. [...] Na spotkanie wyszła straż ogniowa i włościanie na koniach (Pamiętnik Mendla 1929B: 3).

Teraz mamy nowego młodego [rabina]. Kiedy przyjechał do miasta, było lato. Wszyscy, nawet chrześcijanie, wyszli na powitanie. Prowadzono rabina do bóżnicy pod baldachimem z muzyką. Tam przemówił oddzielnie po polsku do polskich gości, dziękował za obecność i życzył, by życie było spokojne i szczęśliwe. Potem była uczta (Surcia 1928: 5).

Odwiedziny znanych osobistości i towarzysząca im ceremonia mogły tworzyć poczucie jedności, choćby powierzchowne i chwilowe, nie tylko między różnymi grupami narodowymi. Rozdarcia i różnice w samej tylko wspólnocie żydowskiej były już w dwudziestoleciu międzywojennym bardzo duże. Rozziew między tradycyjną religijną 
społecznością, a zeświecczonymi zwolennikami syjonizmu nie stwarzał podstaw do codziennych kontaktów i w rezultacie prowadził do poczucia obcości. Tym bardziej szczególne wydają się takie chwile, gdy bariera ta zostawała nieoczekiwanie zniesiona, a chwilowe zbliżenie następowało dzięki muzyce, przekraczającej granice podziałów:

Przybył do Wielunia z niecierpliwością oczekiwany gość Meir Ezrachi. W piątek wieczorem miał referat w Organizacji Syjonistycznej. Wrażenie, jakie wywarł na zebranych potwierdza fakt, który nawet zwrócił uwagę przechodniów: Dzieci z chederów wypadły na ulicę i witały p. Ezrachego pieśnią „Aszrecha”. Dzieci z chederu z pieśnią palestyńską na ustach! Może już nadeszła chwila ogólnego zrozumienia? Może wspólnie przebijemy mur, odgradzający „dzieci chederu” od Erec! (Wieluń. Aszrecha 1929: 8).

Pejzaż dźwiękowy miasteczka zmieniał się również, gdy odwiedzał go wędrowny teatr, cyrk lub objazdowe kino. Muzyka nie tylko rozbrzmiewała przez kilka dni w przestrzeni sztetla, często zostawała później razem z mieszkańcami, którzy w ten sposób poznawali popularny repertuar $\mathrm{z}$ wielkich miast. Dla uboższych dzieci barierą mogły być ceny biletów, lecz także, w przypadku społeczności ortodoksyjnej, różnice obyczajowe. Tradycyjna społeczność sztetla broniła się przed wdzierającą się doń nowoczesnością. Reakcja odmowy uczestnictwa w nowoczesnym świecie, w tym słuchania nowej, świeckiej muzyki, pogłębiała istniejącą stratyfikację społeczną i rozziew między poszczególnymi grupami. Taki przypadek opisał jeden z korespondentów „Małego Przeglądu”:

Wczoraj zdarzyła się ciekawa rzecz. Bencjan, chasyd, nie chciał, żeby córki poszły do teatru, więc zamknął drzwi i postawił łóżko przy drzwiach, żeby córki wyjść nie mogły. Tymczasem jedna wyszła przez okno. Chasyda wykluczono za to ze sztybła. Wielu ojców nie wpuściło swoich córek do domów (Pamiętnik Mendla 1929A: 5).

Powiew nowoczesności pojawiał się $\mathrm{w}$ miasteczkach również wraz $\mathrm{z}$ rozwojem technologii. Zmiany następowały tu znacznie wolniej, niż w dużych miastach. Obecnością radia czy gramofonu mogło się pochwalić zazwyczaj bardzo niewielu mieszkańców. $\mathrm{Ci}$, których było na to stać, czasami umożliwiali dostęp do muzyki swoim sąsiadom, nieraz w tak wymyślnej formie, jak opisany tu koncert:

Byłyśmy w zeszłym tygodniu w szopie, tam był koncert radiowy. Wchodziło się za biletami. Nic nie było warte. Radio wygląda jak gramofon - z czarną trąbą - I ma chrypkę. Jak zaczęło coś śpiewać - wtrącał się jakiś telefon, ktoś głośno mówił i nic nie było wiadomo. [...] Mówią, że w Warszawie jest lepsze radio. [...] U [nas] żadnego nie ma. To na pewno kosztuje strasznie drogo. Tylko bogaci chrześcijanie mają (Na prowincji 1929: 3).

\footnotetext{
9 Być może chodzi o tradycyjną pieśń Aszrecha ma tov chalkecha, śpiewaną ku czci Bar Jochaja.
} 
Radio i gramofon wykorzystywane były też w celach komercyjnych przez sklepy i restauracje. Dla dzieci była to ogromna atrakcja. „Jest jeden gramofon w restauracji polskiej. Jak gramofon gra, wszystkie dzieci stoją przed drzwiami restauracji” - wspominał jeden z korespondentów. I dodawał w zadumie: „My, klasa robotnicza, walczyć musimy o kulturę", wyrażając w ten sposób świadomość ekonomicznych i cywilizacyjnych barier oddzielających uboższą ludność miasteczka od wyższej kultury (Pamiętnik Mendla 1928 A: 3). Głośniki wystawiane na ulicę mogły gromadzić wielu amatorów muzyki, zatrzymujących się na chwilę w drodze do codziennych zajęć, współtworząc nowe sytuacje społeczne, niespotykane do tej pory na ulicach sztetla, będące zdarzeniami o charakterze koncertu, w którym muzyka poddawana jest estetycznej ocenie i słuchana jedynie dla przyjemności.

Z głośnika radiowego na głównej ulicy rozbrzmiewały długie, ckliwe tony skrzypiec. Gromada gapiów stała w blasku lampy ulicznej, przysłuchując się muzyce. Wielu z nich czyniło głośne uwagi na temat koncertu, inni stali cicho, wsłuchując się w muzykę raz dziką, to znów spokojną, z góry ku nim płynącą melodią (Tusia z Będzina 1936: 3).

Być może pewną paralelą do takich ulicznych koncertów mogła być twórczość grajków ulicznych, nie stanowiła jednak wystarczającej konkurencji dla wynalazków techniki i nie była aż tak częsta, jak w dużych miastach. O ile wielkomiejski muzykant uliczny mógł wyrobić sobie markę i czerpać z gry niezły dochód, w małomiasteczkowej społeczności status grajka był niemal równy żebrakowi ${ }^{10}$. Szanujący się muzykanci grywali na weselach (nie tylko żydowskich), gdzie wykonywali muzykę do tradycyjnych tańców, lecz także repertuar o rozmaitej proweniencji: „Pieśni ludowe, cygańskie, pasterskie piosenki, szyte podług żydowskiego smaku, przedostają się na żydowskie wesela, do żydowskich modlitw", wspominał dawne czasy jeden z mieszkańców Mławy (Junis 2016: 89).

Nowym zjawiskiem i zarazem atrakcją implementowaną z życia wielkomiejskiego były parki z przewidzianym podium dla orkiestry, zakładane niekiedy nawet w małych miasteczkach. Muzyka wybrzmiewająca na parkowych scenach pełniła funkcję rekreacyjną, dostarczając rozrywki mieszkańcom miasteczka i była oceniana według walorów estetycznych, podobnie jak to się dzieje w sytuacjach koncertowych. Dla wielu dzieci było to miejsce bardzo ciekawe: „Kiedy tylko mam czas, idę do parku, aby usłyszeć muzykę. W lecie chodzę na plac niedaleko pomnika Kościuszki, gdzie żołnierze

${ }^{10}$ Spotkanie ze śpiewającym żebrakiem opisała jedna z korespondentek „Małego Przeglądu”: „Wracając ze szkoły spostrzegłam leżącego biedaka. Nie miał nóg. Leżał na bruku, bo policjant nie pozwolił mu na chodniku, i śpiewał. Bardzo smutny był ten śpiew. Śpiewał o młodości, o tym, jak mu było dobrze, jak był na wojnie i został kaleką. Kula ścięła mu nogi i teraz musi włóczyć się na kolanach, aż mdleje ze zmęczenia" (Gucia 1928: 8). 
i muzykanci ładnie grają. Całymi dniami stoję tam i gapię się", wspominał mały mieszkaniec Otwocka (Bernard z Otwocka 1933: 6).

$\mathrm{Z}$ przedstawionego materiału udokumentowanego we wspomnieniach dzieci wyłania się obraz miasteczka, w którym muzyka pełniła bardzo ważną rolę jako część dźwiękowego pejzażu. Najważniejsza wydaje się jej funkcja integracyjna, a także religijna oraz ideologiczna, w dwudziestoleciu międzywojennym szybko zyskująca na znaczeniu.Muzyka związana z praktykami religijnymi dominowała jednakwciążw dźwiękowym krajobrazie.

Wiele typowych, tradycyjnych sztetli zachowało kształt sprzed lat i dawne obyczaje, rozgrywające się w niezmiennej scenerii. I choć niektórzy zdawali sobie sprawę z nieuchronnych zmian, nikt nie przewidział, że nastąpi całkowita zagłada, kładąca kres miasteczkom i ich mieszkańcom. Wraz z nimi odszedł w niepamięć bogaty dźwiękowy krajobraz, na który składała się przede wszystkim obecność Żydów, ich język, pieśni, zabawy, modlitwy, a także cały miasteczkowy gwar codziennej pracy, który tworzyli. Rekonstrukcja tego zjawiska jest niemożliwa, lecz zachowane okruchy pamięci przybliżają nam choć trochę ten świat, który od stuleci kształtował oblicze polskiej prowincji i znaczącego udziału, jaki wnieśli do niego polscy Żydzi.

\section{Bibliografia}

Adler S. 2020. I znowu jestem Żydem. Warszawa: Multart.

[Anonim] 1930. Kuczki. Przez szparkę. Maty Przeglad 39, 2.

[Anonim] 1929. Lag Baomer. Maty Przeglad 21, 1.

[Anonim] 1929. Na prowincji. Maty Przeglad 14, 3.

[Anonim] 1929. Nasze gospodarstwo. Purym. Maty Przeglad 12, 1.

[Anonim] 1928 A. Pamiętnik Mendla. Maty Przegląd 116, 3.

[Anonim] 1928 B. Pamiętnik Mendla. Maty Przeglad 117, 2.

[Anonim] 1929 A. Pamiętnik Mendla. Maty Przeglad 5, 5.

[Anonim] 1929 B. Pamiętnik Mendla. Maty Przeglad 7, 3.

[Anonim] 1928. Walka dzieci o swoje prawa. Maty Przeglad 75, 6-7.

[Anonim] 1929. Z miast i miasteczek. Wieluń. Aszrecha. Maty Przeglad 25, 8.

Bernard z Otwocka. 1933. Lubię muzykę. Maty Przeglą 48, 6.

Chrabotowski J. 2017. Sport i nie tylko. [W:] W. Konończuk et al. (red.), Księga Pamięci Żydów Bielska Podlaskiego. Bielsk Podlaski: Stowarzyszenie Muzeum Małej Ojczyzny w Studziwodach.

Gucia 1928. Z miast i miasteczek. Wieluń. Kaleka. Maty Przeglad 91, 8.

Hanka ze Złotej 1931. Ulica. Miasteczko w piątek. Maty Przeglad 4, 3.

Hinda 1928. Z miast i miasteczek. Sierpc. Przyjazd Pana Prezydenta. Maty Przeglad 114, 3.

Jankiel 1931. Gdy Żydzi są dziećmi. Maty Przegląd 39, 2-3.

Jankiel 1932. Przed świętami. Maty Przegląd 40, 1.

Jakób z Ostrołęki 1930. Rosz Haszana i Jom Kipur.W miasteczku. Maty Przegląd 39, 1. 
Junis Z. 2016. Stary dom. [W:] L.Zygner (red.), Księga pamięci Żydów mtarwskich. Stacja Naukowa im. prof. Stanisława Herbsta w Mławie.

Kanarek M. 2016. Życie i gospodarka - praca i rozrywka w miasteczku. [W:] S. Gutkowski (red.), Ksiegga o Serocku. Niezatarte historie. Pułtusk: Wydawnictwo Aleksander.

Kijek K. 2017. Dzieci modernizmu. Świadomość, kultura i socjalizacja polityczna mtodzieży żydowskiej w II Rzeczpospolitej. Wrocław: Wydawnictwo Uniwersytetu Wrocławskiego.

Lutek 1929. Święto Niepodległości. Prowincja. Ostrów. Maty Przegląd 48, 4.

Muszkalska B. 2012. Studies of soundscapes of polish cities. The case of Wrocław. Urban People/ Lidé Města, Zuzanna Jurková (red.), nr 14, Praha: Fakulta Humanitních Studií Univerzity Karlovy, 255-266.

Petrovsky-Shtern Y. 2014. Sztetl. Rozkwit i upadek żydowskich miasteczek na Kresach Wschodnich, Kraków: Wydawnictwo Uniwersytetu Jagiellońskiego.

Surcia 1928. Nasze miasteczka. Rabin. Maty Przeglad 69, 5.

Szlamek z Otwocka 1931. Purim-szpiler. Maty Przeglad 9, 3.

Teller A. 2004. Shtetl as an arena of Polish-Jewish integration in the Eighteenth Century. Polin $17,25-40$.

Tusia z Będzina 1936. Muzyka. Maty Przeglad 4, 6.

\section{Źródła internetowe}

Kassow S. Shtetl. [W:] The YIVO Encyclopedia of Jews in Eastern Europe New Haven, CT: Yale University Press,2008.http://www.yivoencyclopedia.org/article.aspx/Shtetl12.12.2020

Autorka:

Mgr Agnieszka Jeż

e-mail: a.jez3@uw.edu.pl 